\begin{tabular}{ll|l}
\cline { 2 - 3 } & $\begin{array}{l}\text { Intervent Neurol 2017;6:126-134 } \\
\text { DOI: 10.1159/000456552 } \\
\text { Published online: February 22, 2017 }\end{array}$ & $\begin{array}{l}\text { C) 2017 S. Karger AG, Basel } \\
\text { www.karger.com/ine }\end{array}$ \\
\end{tabular}

\title{
Anterior Communicating Artery Aneurysm Treatment with the Pipeline Embolization Device: A Single-Center Experience with Long-Term Follow-Up
}

\author{
Ali Sultan-Qurraie Ahsan Sattar Wled Wazni Mazen Noufal \\ Osama Zaidat \\ Department of Neurology, Medical College of Wisconsin, Milwaukee, WI, USA
}

\section{Keywords}

Brain aneurysm · Intracerebral aneurysm · Recanalization · Stents - Endovascular procedures

\begin{abstract}
Introduction: The pipeline embolization device (PED) is increasingly used in the endovascular management of cerebral aneurysms. Longitudinal data regarding safety and benefit of the PED in anterior communicating (ACOM) artery aneurysms are limited and particularly lacking in residual ACOM artery aneurysms. We report the use of the PED in 3 patients with ACOM artery aneurysms who were previously coiled. Methods: Three patients with ACOM artery aneurysms, all previously treated with coiling and with recurrence of the aneurysm neck, were treated with the PED. All obtained follow-up diagnostic cerebral angiograms at either 3 or 6 months. Results: Mean age of patients was 59 years. All patients received cerebral angiograms at a minimum of 3 months after treatment with the PED. Follow-up angiography was performed up to a mean of 10 months at which time point all cases demonstrated complete aneurysm occlusion, without any stenosis in the parent artery. Conclusion: The PED can be safely used for the treatment of ACOM artery aneurysms. Complete aneurysm obliteration can be achieved in cases refractory to endovascular coiling. These findings warrant replication in a larger data set.

(c) 2017 S. Karger AG, Basel
\end{abstract}




\section{Introduction}

Randomized evidence has demonstrated the benefit of the endovascular treatment of both ruptured and unruptured cerebral aneurysms [1, 2]. Long-term follow-up of the International Subarachnoid Hemorrhage Trial indicates a significantly lower risk of death at 5 years with coiling compared to clipping; however, rebleed rates are relatively higher [1]. Incomplete aneurysm occlusion or aneurysm recurrence is postulated to be a risk factor for aneurysm rehemorrhage [3, 4]. An estimated $20.8 \%$ of aneurysms exhibit recurrence at follow-up after endovascular coiling [5].

Advances in endovascular therapy have likely reduced aneurysm recurrence after treatment [6]. New devices, such as the pipeline embolization device (PED; ev3/Covidien, Irvine, CA, USA), have also enabled the treatment of a wider array of aneurysm types. PED is a "flow diverter," of braided platinum (25\%) and nickel-cobalt-chromium (75\%), placed endoluminally across the "neck" of an aneurysm, diverting blood flow from the aneurysm and resulting in occlusion/thrombosis within the aneurysm. The FDA approved the use of the PED in the United States in April 2011 for the treatment of "adults with large or giant wide-necked aneurysms in the internal carotid artery from the petrous to the superior hypophyseal segments" [7]. This approval was largely based on safety data from Becske et al. [8] in which $74 \%$ of aneurysms treated with the PED remained occluded after 6 months without significant stenosis of the parent artery [8]. Other studies have suggested higher rates of aneurysm occlusion, especially when PED use is coupled with coiling $[9,10]$.

While the use of the PED has become increasingly common, longitudinal data for its use in certain arterial regions is limited, such as for the treatment of anterior communicating (ACOM) artery aneurysms. Reports of PED use in this arterial region for aneurysms refractory to primary coiling are even more lacking. We report 3 patients with ACOM artery aneurysms, refractory to endovascular coiling, treated with the PED.

\section{Patients}

Our study was conducted in compliance with our Institutional Review Board. Three patients with remnant or recurrent ACOM artery aneurysms who had initially been treated with primary coiling were identified. Two had suffered aneurysm rupture. Informed written consent was obtained from all patients. In each

Table 1. Patients, aneurysm, and ACA characteristics

\begin{tabular}{|c|c|c|c|c|c|c|c|}
\hline Patient & Gender & $\begin{array}{l}\text { Age, } \\
\text { years }\end{array}$ & Presentation & $\begin{array}{l}\text { Initial aneurysm } \\
\text { size, based on catheter } \\
\text { angiogram, mm }\end{array}$ & $\begin{array}{l}\text { A1 vessel size and } \\
\text { flow direction }\end{array}$ & $\begin{array}{l}\text { Pre- } \\
\text { treatment } \\
\text { mRS score }\end{array}$ & $\begin{array}{l}\text { 3-month } \\
\text { mRS } \\
\text { score }\end{array}$ \\
\hline 1 & M & 68 & Unruptured & $\begin{array}{l}5.4 \text { (width) } \\
6.1 \text { (height) } \\
3.7 \text { (neck) }\end{array}$ & $\begin{array}{l}\text { Right } 1.3 \mathrm{~mm} \\
\text { Left } 2.2 \mathrm{~mm} \\
\text { Flow: Left to right across ACOM }\end{array}$ & 0 & 0 \\
\hline 2 & $\mathrm{~F}$ & 47 & Ruptured & $\begin{array}{l}12.2 \text { (width) } \\
15.7 \text { (height) } \\
5.3 \text { (neck) }\end{array}$ & $\begin{array}{l}\text { Left } 2.1 \mathrm{~mm} \\
\text { Right } 1.5 \mathrm{~mm} \\
\text { Flow: Bidirectional across ACOM }\end{array}$ & 1 & 1 \\
\hline 3 & M & 63 & Ruptured & $\begin{array}{l}3.6 \text { (width) } \\
5 \text { (height) } \\
3.6 \text { (neck) }\end{array}$ & $\begin{array}{l}\text { Left } 2.1 \mathrm{~mm} \\
\text { Right } 1.9 \mathrm{~mm} \\
\text { Flow: Bidirectional across ACOM }\end{array}$ & 0 & 0 \\
\hline
\end{tabular}

ACA, anterior cerebral artery; mRS, modified Rankin scale. 


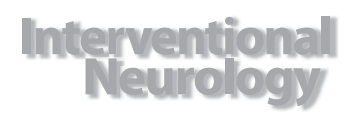

\begin{tabular}{l|l}
\hline \multicolumn{2}{|l|}{ Intervent Neurol 2017;6:126-134 } \\
\hline DOI: 10.1159/000456552 & $\begin{array}{l}\text { C 2017 S. Karger AG, Basel } \\
\text { www.karger.com/ine }\end{array}$ \\
\hline
\end{tabular}

Sultan-Qurraie et al.: Anterior Communicating Artery Aneurysm Treatment with the Pipeline Embolization Device: A Single-Center Experience with Long-Term Follow-Up

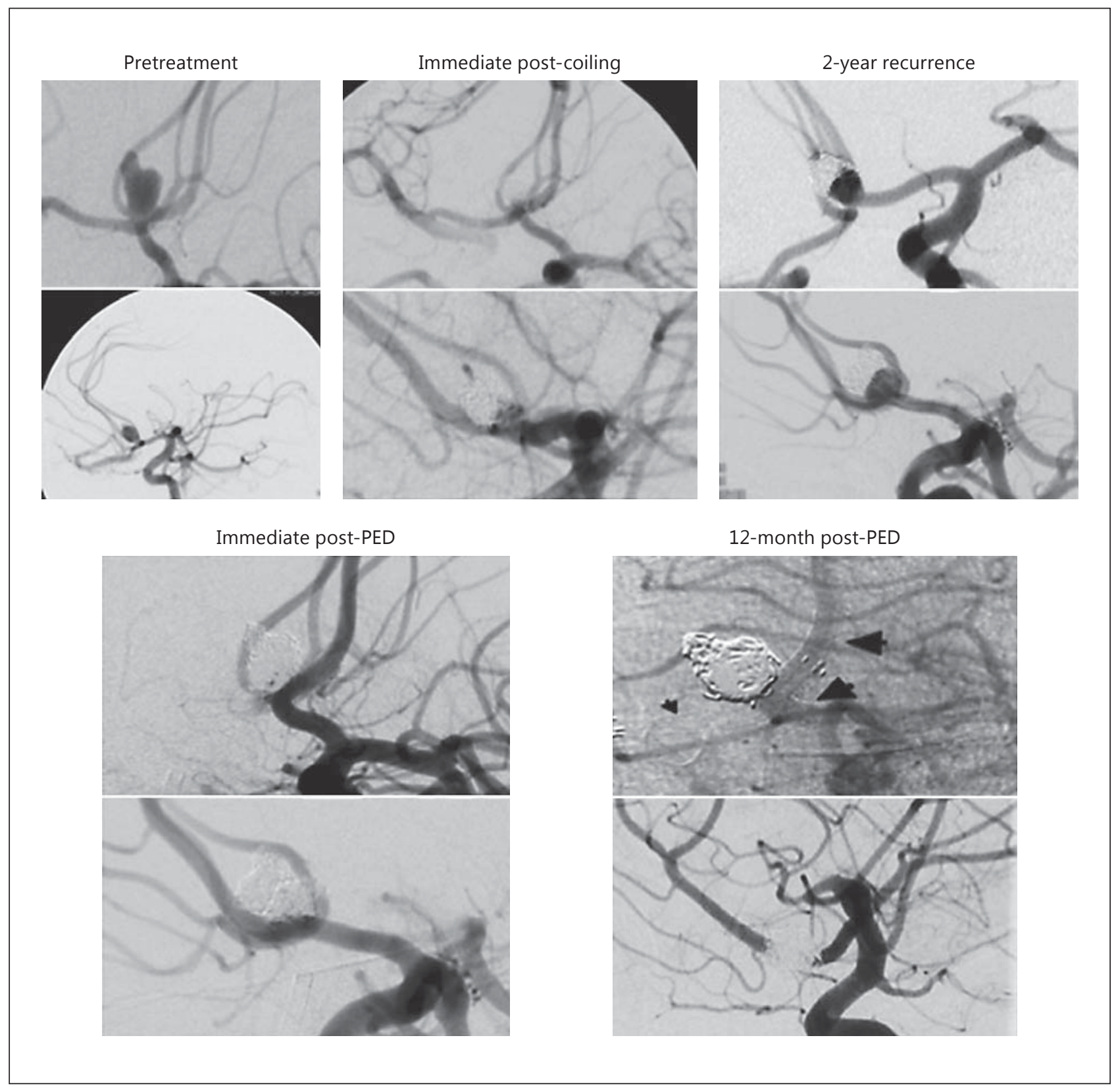

Fig. 1. Anteroposterior (top) and lateral (bottom) images of pretreatment, immediate post-coiling, postcoiling recurrence, immediate post-PED, and 12-month follow-up after PED (PED marked by large arrows; Neuroform stent marked by small arrow).

case, pretreatment angiogram was performed to confirm a "simple" ACOM artery, one without significant perforator vessels. Endovascular parent reconstruction and aneurysm occlusion was achieved in all cases using the PED. All patients were treated with dual antiplatelets for a minimum of 5 days prior to PED placement. Platelet function testing was done prior to each procedure with a target of $<220$ P2Y12 reaction units for clopidogrel and $<550$ aspirin reaction units for aspirin. All patients were heparinized after arterial access with a target activated clotting time of 250-300. None of the patients were reversed after the case was finished. An 8 Fr $\times 80 \mathrm{~cm}$ Neuron Max 088 (Penumbra, Alameda, CA, USA) catheter through an $8 \mathrm{Fr} \times 55 \mathrm{~cm}$ Raabe (Cook Medical, Bloomington, IN, USA) sheath was used in all cases. 


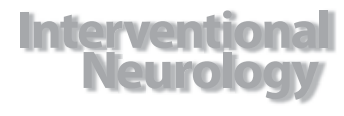

Sultan-Qurraie et al.: Anterior Communicating Artery Aneurysm Treatment with the Pipeline Embolization Device: A Single-Center Experience with Long-Term Follow-Up

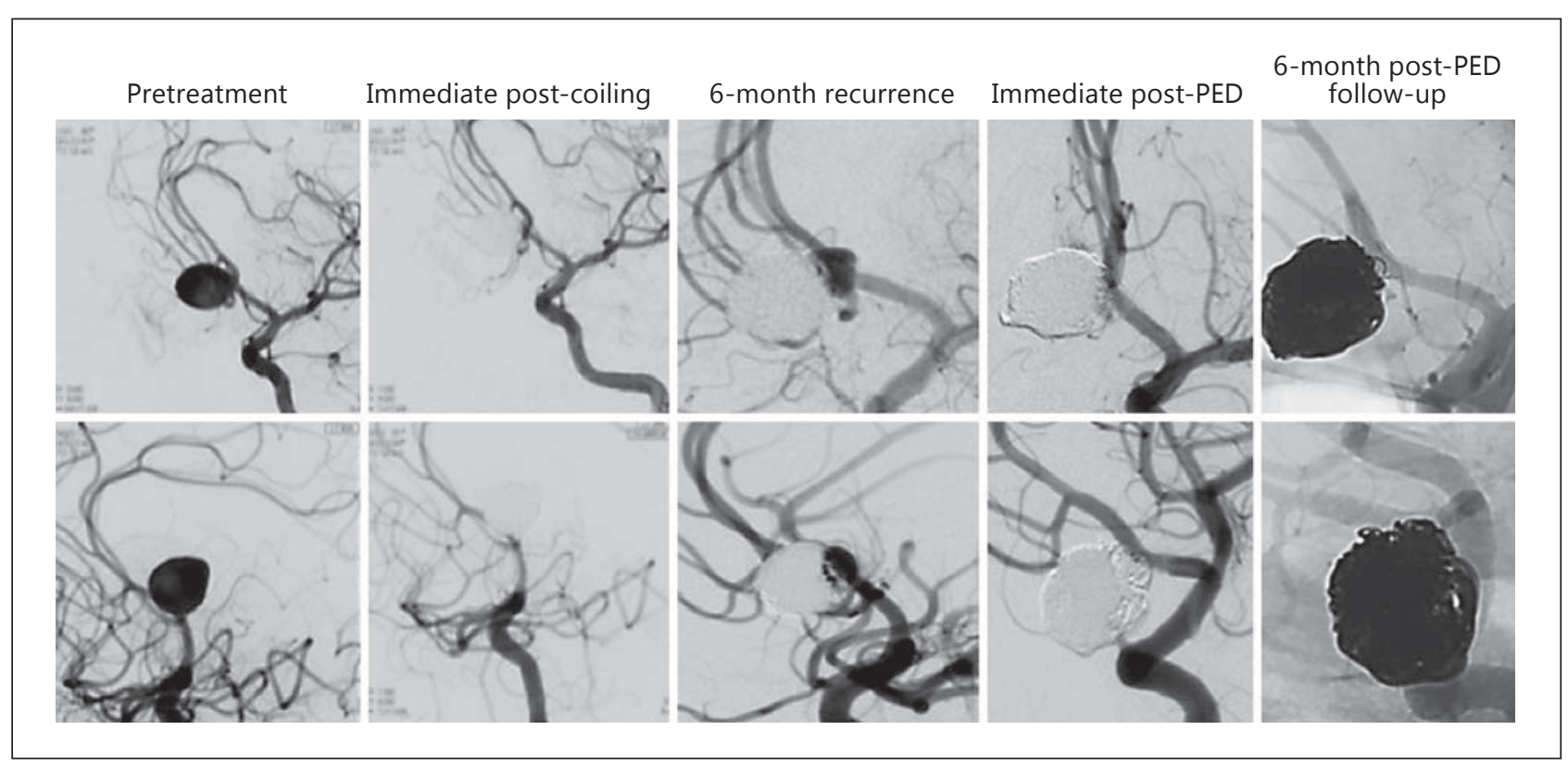

Fig. 2. Anteroposterior (top row) and lateral (bottom row) images of pretreatment, post-coiling, recurrence, immediate post-PED, and 6-month follow-up post-PED.

\section{Results}

Mean age of our patients was 59 years. Mean follow-up angiography time was 10 months (Table 1).

\section{Patient 1}

A 68-year-old man was discovered to have an unruptured superior and anterior projecting 8-mm ACOM artery aneurysm. The aneurysm was coiled, with follow-up angiogram suggesting total aneurysm obliteration. However, 2 years after treatment, residual filling was noted. The patient was treated with a $3 \times 16 \mathrm{~mm}$ PED through an XT-27 microcatheter (Stryker, Fremont, CA, USA) via a left anterior cerebral artery (ACA) approach. The PED was deployed between the proximal left $\mathrm{A} 2$ and the distal left A1. Additional coiling was performed via a jailed microcatheter next to the PED and a Neuroform stent (Stryker), which was placed within the contralateral right ACA. Follow-up angiography 6 and 12 months later revealed persistent and complete aneurysm occlusion and a widely patent stent with good wall apposition without evidence of in-stent stenosis or thrombosis (Fig. 1).

\section{Patient 2}

A 46-year-old woman initially presented with a ruptured ACOM artery aneurysm (Hunt and Hess grade 2/Fisher grade 3). A large, $15.7 \times 12.2 \mathrm{~mm}$ aneurysm with a 5.3-mm neck was treated with primary coil embolization. The 6-month diagnostic angiogram revealed aneurysm recurrence of $4.23 \mathrm{~mm}$ in height $\times 9 \mathrm{~mm}$ in width at the aneurysm's neck. Eight months after initial coil embolization, she was treated with the PED. A $2.5 \times 14 \mathrm{~mm}$ PED was coaxially introduced through a Marksman microcatheter (ev3/Covidien) across the neck of the aneurysm, with its distal end in the proximal left A2 and the proximal end at the mid-left A1. Diagnostic angiogram 6 months later showed good vessel wall apposition and no evidence of aneurysm recanalization or neck residual (Fig. 2). 

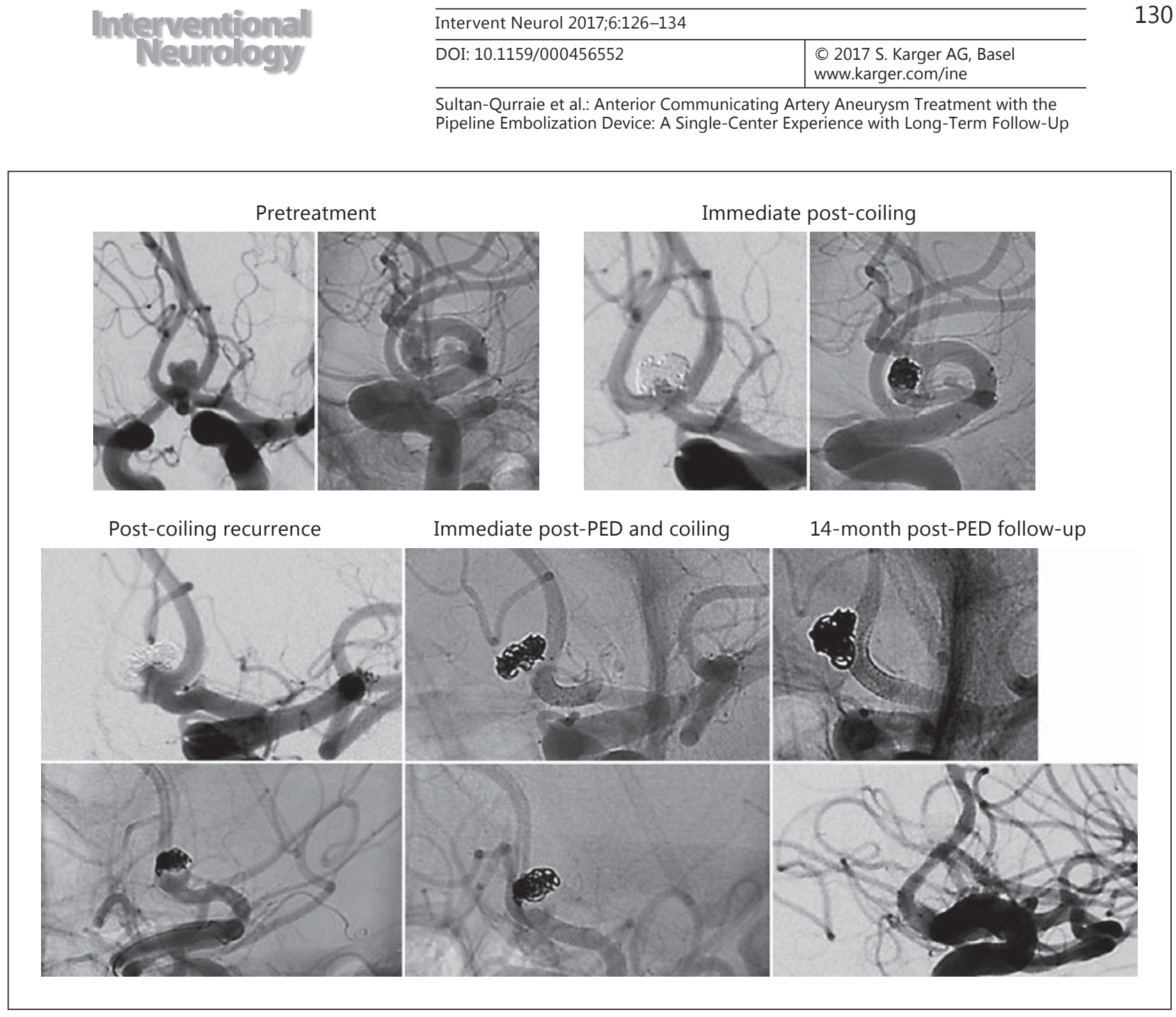

Fig. 3. Anteroposterior (left: pretreatment and immediate post-coiling; top row: post-coiling recurrence, immediate post-PED, and 14-month post-PED follow-up) and lateral images of pretreatment, post-coiling, recurrence, immediate post-PED, and 14-month follow-up post-PED.

\section{Patient 3}

A 64-year-old man presented with a ruptured ACOM artery aneurysm (Hunt and Hess grade 4/Fisher grade 4). He was treated with primary endovascular coiling. The 6-month follow-up angiogram revealed a 1-mm remnant/recurrent aneurysm neck. MRA several years later demonstrated persistent aneurysm with a slight increase in size. Cerebral angiogram at this point demonstrated neck remnants measuring $2 \mathrm{~mm}$ in height and $4.9 \mathrm{~mm}$ in width. The patient underwent a $2.5 \times 12 \mathrm{~mm}$ PED placement between the left A1 and A2 segments of the ACA through an XT-27 microcatheter. As the wire was captured back into the XT-27 microcatheter, there was proximal migration of the PED; a second pipeline device was deployed to adequately cover the neck of the aneurysm. The second PED, $2.75 \times 12 \mathrm{~mm}$, was advanced through the XT-27 microcatheter and deployed with its distal end in the proximal left $\mathrm{A} 2$ and the proximal end overlapping with the previously placed pipeline; the overlapped segment adequately covered the neck of the aneurysm. Coiling of the residual ACOM aneurysm was performed via the right internal carotid artery (ICA). Immediate post-procedure cerebral angiogram showed near occlusion; 3- and 14-month cerebral angiograms showed complete occlusion of the aneurysm (Fig. 3). 
Fig. 4. Green highlight depicts the ideal PED landing zone. Graphic courtesy of Yasmin Daneshjoo, adapted from El Falougy et al. [21].

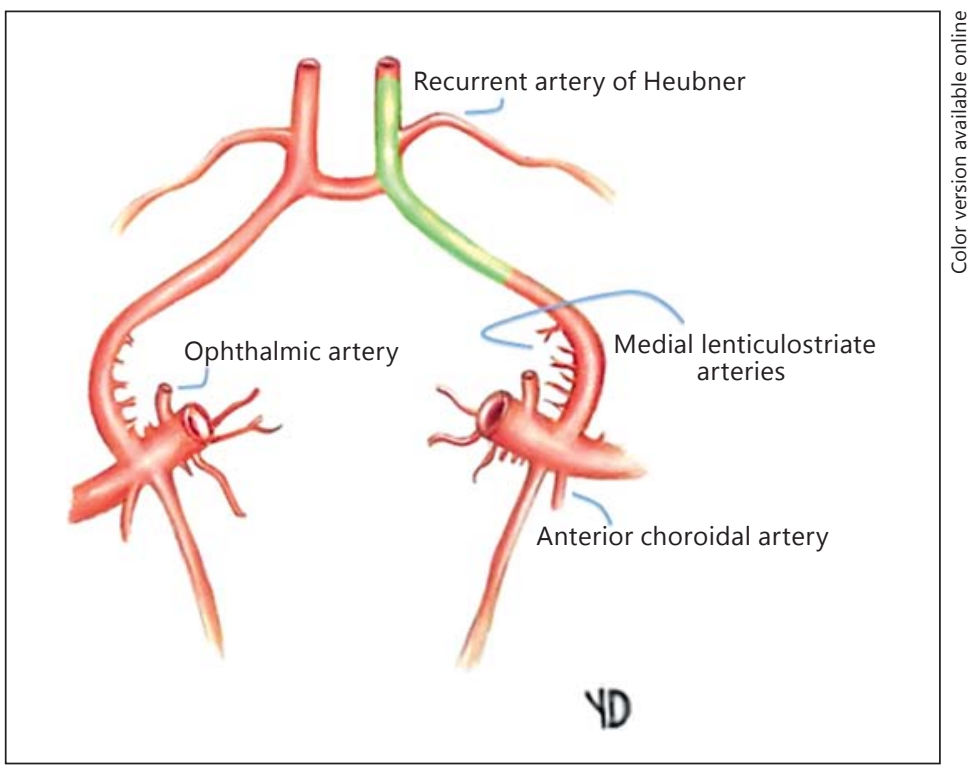

\section{Discussion}

Cerebral aneurysms most commonly occur in the anterior circulation and are frequently located at branch points of the circle of Willis [11]. Risk of aneurysm rupture depends on various factors including location and size [12]. Multiple independent epidemiologic studies have found that aneurysms in the ACOM artery distribution are at highest risk for rupture [13-15]. Despite their relative prevalence and risk of rupture, there is limited follow-up data on the use of PED - and flow diverters in general - in the treatment of ACOM artery aneurysms. Specifically, there is limited data regarding PED use in patients with incomplete aneurysm occlusion following endovascular coiling.

Aneurysm recurrence is not infrequent after primary coiling - a recent meta-analysis suggests $20 \%$ recurrence [5]. In addition, only an estimated $62.3 \%$ of coiled aneurysms achieve complete initial occlusion [1,5]; therefore, more than half of all coiled aneurysms are susceptible to incomplete occlusion. This could portend risk of rupture, further growth, and patient anxiety. Moreover, microsurgical treatment of ACOM artery aneurysms is wrought with its own challenges, further supporting the need for a safe and durable endovascular option [16].

Occlusion of small perforating vessels has been reported with the use of the PED [17]. It is noteworthy that ischemic stroke did not occur in any of our patients. This is owed, in part, to the vascular anatomy of the ACA. The A1 and A2 junction lends itself to the use of the PED given the paucity of side branch perforators. Particular awareness should be given to the medial lenticulostriate vessels, small perforators that authors variably note to originate from either the proximal middle cerebral artery or the proximal half of the A1 ACA [18-20]. Awareness of the origin of these relatively small vessels informs the neurointerventionalist of the PED's ideal landing zone (Fig. 4). This region spans the distal half of the A1 segment, A1-A2 junction, and proximal A2. The recurrent artery of Heubner (RAH or medial striate artery) is the most prominent lenticulostriate vessel arising from this region. It most often arises from the proximal A2 (48-78\%), but can also arise from the ACOM artery or distal A1; Rhoton and colleagues state that it arises within $4 \mathrm{~mm}$ of the A1-A2 junction in $95 \%$ of cases [21-23]. The RAH supplies portions of the caudate, internal capsule, 

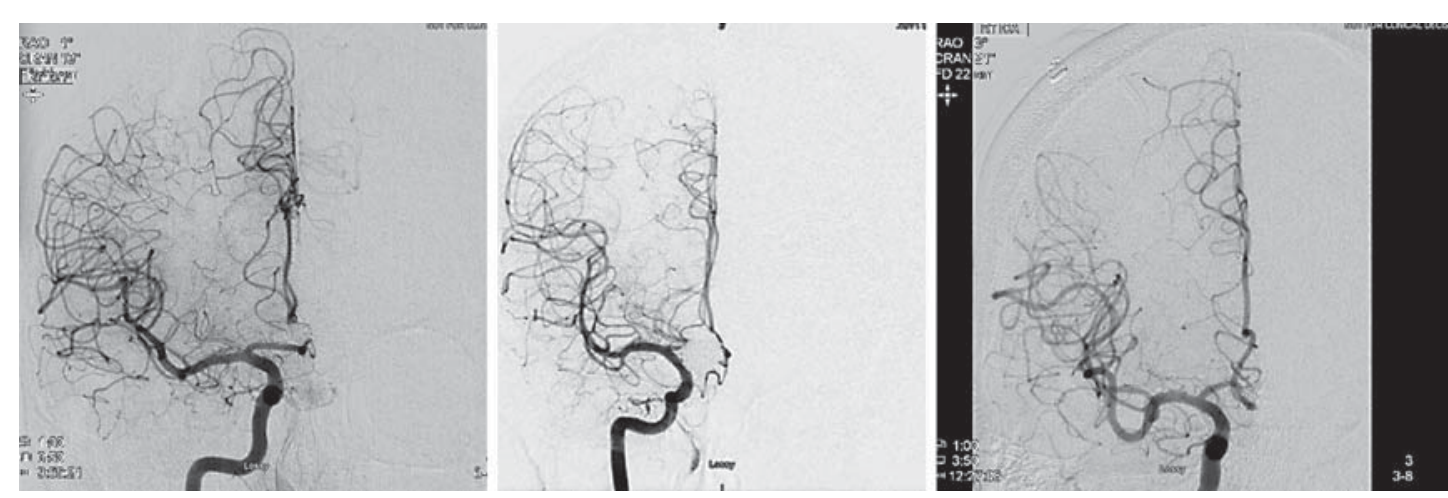

Fig. 5. Frontal projection of ICA injection contralateral to the side of PED placement demonstrating patency of the contralateral ACA in each case, 1-3, from left to right.

paraterminal gyrus, and putamen and therefore care is taken to preserve this vessel during microsurgical clipping of ACOM artery aneurysms [23]. However, to our knowledge, jailing (covering) this vessel with the PED has not been reported to cause infarction. Although technically a lenticulostriate vessel, the RAH is notably larger than the medial lenticulostriate vessels and, with a diameter of $\sim 1 \mathrm{~mm}$, it approximates to that of the ophthalmic artery $(0.7-1.8 \mathrm{~mm})$ and anterior choroidal artery $(\sim 0.94 \mathrm{~mm})$, vessels that can be safely jailed when the PED is used according to its FDA approval in the distal ICA [22, 24-27]. With regards to the ACOM artery itself, in normal physiologic conditions with equal bilateral A1 flow rates, net flow across the ACOM artery is absent. Indeed, elevated hemodynamic force from cross-flow is postulated to promote the formation and growth of ACOM artery aneurysms $[28,29]$. In our cases, post-PED images suggest diminished contralateral ACA flow with ipsilateral ICA injection. We confirmed the unaltered patency of the contralateral ACA by a contralateral ICA injection (Fig. 5). Competitive A1 flow, as in normal hemodynamic conditions, is the most likely explanation for the apparent change in the ACOM artery's filling status post-PED. Nonetheless, although none of our patients suffered from stroke, until larger studies investigating the effect of PED at the A1-A2 junction are reported, in our opinion, PED placement should be limited to "simple" ACOM arteries, those without large perforating vessels.

Few other authors have reported their experience with PED in the ACOM artery territory. Pistocchi et al. [30] report 11 ACOM artery aneurysms treated with the Silk Embolization Device (SILK; Balt Extrusion, Montmorency, France) and 1 recurrent ACOM artery aneurysm treated with the PED. Lin et al. [31] report 2 ACOM artery aneurysms treated with the PED. Gawlitza et al. [32] also report 3 recurrent ACOM artery aneurysms treated with the PED with a median time to follow-up digital subtraction angiography of 4 months. More recently, Dabus et al. [33] reported 13 patients with ACOM artery aneurysms treated with the PED; 12 patients had a mean time to angiographic follow-up of approximately 9 months.

Although approved for ICA segment aneurysms, our findings demonstrate that the PED can safely and effectively be used as an adjunct therapy for ACOM artery aneurysms. There were no thromboembolic complications, none of the patients had any adverse neurological symptoms, and complete angiographic aneurysm occlusion was observed in all cases. 


\section{Conclusion}

Initial subtotal occlusion and aneurysm recurrence are shortcomings of primary endovascular coiling. Although off-label, our series demonstrates that previously coiled ACOM artery aneurysms with remnants or recurrence can safely and completely be treated with the PED. These findings should be replicated in a larger data set.

\section{Disclosure Statement}

The authors declare that they have no conflicts of interest.

\section{References}

1 Molyneux AJ, Kerr RS, Yu LM, Clarke M, Sneade M, Yarnold JA, Sandercock P; International Subarachnoid Aneurysm Trial (ISAT) Collaborative Group: International Subarachnoid Aneurysm Trial (ISAT) of neurosurgical clipping versus endovascular coiling in 2,143 patients with ruptured intracranial aneurysms: a randomised comparison of effects on survival, dependency, seizures, rebleeding, subgroups, and aneurysm occlusion. Lancet 2005;366:809-817.

2 Spetzler RF, McDougall CG, Albuquerque FC, Zabramski JM, Hills NK, Partovi S, Nakaji P, Wallace RC: The Barrow Ruptured Aneurysm Trial: 3-year results. J Neurosurg 2013;119:146-157, erratum in J Neurosurg 2014;120:581.

3 Johnston SC, Dowd CF, Higashida RT, Lawton MT, Duckwiler GR, Gress DR; CARAT Investigators: Predictors of rehemorrhage after treatment of ruptured intracranial aneurysms: the Cerebral Aneurysm Rerupture after Treatment (CARAT) study. Stroke 2008;39:120-125.

4 Crobeddu E, Lanzino G, Kallmes DF, Cloft HJ: Review of 2 decades of aneurysm-recurrence literature, part 2: managing recurrence after endovascular coiling. AJNR Am J Neuroradiol 2013;34:481-485.

5 Ferns SP, Sprengers ME, van Rooij WJ, et al: Coiling of intracranial aneurysms: a systematic review on initial occlusion and reopening and retreatment rates. Stroke 2009; 40:e523-e529.

6 Murayama Y, Nien YL, Duckwiler G, Gobin YP, Jahan R, Frazee J, Martin N, Viñuela F: Guglielmi detachable coil embolization of cerebral aneurysms: 11 years' experience. J Neurosurg 2003;98:959-966.

7 http://www.accessdata.fda.gov/cdrh_docs/pdf10/p100018a.pdf (accessed October 4, 2015).

8 Becske T, Kallmes DF, Saatci I, McDougall CG, Szikora I, Lanzino G, Moran CJ, Woo HH, Lopes DK, Berez AL, Cher DJ, Siddiqui AH, Levy EI, Albuquerque FC, Fiorella DJ, Berentei Z, Marosfoi M, Cekirge SH, Nelson PK: Pipeline for uncoilable or failed aneurysms: results from a multicenter clinical trial. Radiology 2013;267:858-868.

9 Lin N, Brouillard AM, Krishna C, Mokin M, Natarajan SK, Sonig A, Snyder KV, Levy EI, Siddiqui AH: Use of coils in conjunction with the pipeline embolization device for treatment of intracranial aneurysms. Neurosurgery 2015;76:142-149.

10 Nelson PK, Lylyk P, Szikora I, Wetzel SG, Wanke I, Fiorella D: The pipeline embolization device for the intracranial treatment of aneurysms trial. AJNR Am J Neuroradiol 2011;32:34-40.

11 Schievink WI: Intracranial aneurysms. N Engl J Med 1997;336:28.

12 Wiebers DO, Whisnant JP, Huston J 3rd, Meissner I, Brown RD Jr, Piepgras DG, Forbes GS, Thielen K, Nichols D, O’Fallon WM, Peacock J, Jaeger L, Kassell NF, Kongable-Beckman GL, Torner JC; International Study of Unruptured Intracranial Aneurysms Investigators: Unruptured intracranial aneurysms: natural history, clinical outcome, and risks of surgical and endovascular treatment. Lancet 2003;362:103-110.

13 Bijlenga P, Ebeling C, Jaegersberg M, Summers P, Rogers A, Waterworth A, Iavindrasana J, Macho J, Pereira VM, Bukovics P, Vivas E, Sturkenboom MC, Wright J, Friedrich CM, Frangi A, Byrne J, Schaller K, Rufenacht D; @ neurIST Investigators: Risk of rupture of small anterior communicating artery aneurysms is similar to posterior circulation aneurysms. Stroke 2013;44:3018-3026.

14 Lee HS, Kim YJ, You SH, Jang YG, Rhee WT, Lee SY: The incidence of aneurysmal subarachnoid hemorrhage in youngdong district, Korea. J Korean Neurosurg Soc 2007;42:258-264.

15 Morita A, Kirino T, Hashi K, Aoki N, Fukuhara S, Hashimoto N, Nakayama T, Sakai M, Teramoto A, Tominari S, Yoshimoto T; UCAS Japan Investigators: The natural course of unruptured cerebral aneurysms in a Japanese cohort. N Engl J Med 2012;366:2474-2482.

16 Sekhar LN, Natarajan SK, Britz GW, Ghodke B: Microsurgical management of anterior communicating artery aneurysms. Neurosurgery 2007;61(5 suppl 2):273-290, discussion 290-292.

17 van Rooij, Sluzewski M: Perforator infarction after placement of a pipeline flow-diverting stent for an unruptured A1 aneurysm. AJNR Am J Neuroradiol 2010;31:E43-E44.

18 Bogousslavsky J, Caplan LR: Stroke Syndromes. Cambridge, Cambridge University Press, 2001.

19 Osborn AG: Diagnostic Cerebral Angiography. Philadelphia, Lippincott, 1999. 
Sultan-Qurraie et al.: Anterior Communicating Artery Aneurysm Treatment with the

20 Jabbour PM: Neurovascular Surgical Techniques. New Delhi, Jaypee Brothers Medical Publishers, 2013.

21 El Falougy H, Selmeciova P, Kubikova E, Haviarová Z: The variable origin of the recurrent artery of Heubner: an anatomical and morphometric study. Biomed Res Int 2013;2013:873434.

22 Perlmutter D, Rhoton AL Jr: Microsurgical anatomy of the anterior cerebral-anterior communicating-recurrent artery complex. J Neurosurg 1976;45:259-272.

23 Morris P: Practical Neuroangiography. Philadelphia, Williams and Wilkins, 2006, pp 63-75.

24 Michalinos A, Zogana S, Kotsiomitis E, Mazarakis A, Troupis T: Anatomy of the ophthalmic artery: a review concerning its modern surgical and clinical applications. Anat Res Int 2015;2015:591961.

25 Uz A, Erbil K, Esmer A: The origin and relations of the anterior choroidal artery: an anatomical study. Folia Morphol (Warsz) 2005;64:269-272.

26 Puffer RC, Kallmes DF, Cloft HYJ, Lanzino GE: Patency of the ophthalmic artery after flow diversion treatment of paraclinoid aneurysms: clinical article. J Neurosurg 2012;116:892-896.

27 Raz E, Shapiro M, Becske T, Zumofen DW, Tanweer O, Potts MB, Riina HA, Nelson PK: Anterior choroidal artery patency and clinical follow-up after coverage with the pipeline embolization device. AJNR Am J Neuroradiol 2015;36:937-942.

28 Ujiie H, Liepsch DW, Goetz M, Yamaguchi R, Yonetani H, Takakura K: Hemodynamic study of the anterior communicating artery. Stroke 1996;27:2086-2093, discussion 2094.

29 Jou LD, Lee DH, Mawad ME: Cross-flow at the anterior communicating artery and its implication in cerebral aneurysm formation. J Biomech 2010;43:2189-2195.

30 Pistocchi S, Blanc R, Bartolini B, Piotin M: Flow diverters at and beyond the level of the circle of Willis for the treatment of intracranial aneurysms. Stroke 2012;43:1032-1038.

31 Lin N, Lanzino G, Lopes DK, Arthur AS, Ogilvy CS, Ecker RD, Dumont TM, Turner RD 4th, Gooch MR, Boulos AS, Kan P, Snyder KV, Levy EI, Siddiqui AH: Treatment of distal anterior circulation aneurysms with the pipeline embolization device: a US multicenter experience. Neurosurgery 2016;79:14-22.

32 Gawlitza M, Januel AC, Tall P, Bonneville F, Cognard C: Flow diversion treatment of complex bifurcation aneurysms beyond the circle of Willis: a single-center series with special emphasis on covered cortical branches and perforating arteries. J Neurointerv Surg 2016;8:481-487.

33 Dabus G, Grossberg JA, Cawley CM, Dion JE, Puri AS, Wakhloo AK, Gonsales D, Aguilar-Salinas P, Sauvageau E, Linfante I, Hanel RA: Treatment of complex anterior cerebral artery aneurysms with pipeline flow diversion: mid-term results. J Neurointerv Surg 2017;9:147-151. 